\title{
Consumer-Complainant's Contentment with Reference to Performance of Consumer Dispute Redressal Machinery
}

\author{
Marinal Gupta, Sarang Narula
}

\begin{abstract}
Recognizing the significance of customer retention and creation, customer centric firms are continuously and systematically measuring customer satisfaction in terms of how well their customers are being treated and what are the factors influencing customer satisfaction level. Even when conscious efforts are being made by the business to keep its customers satisfied, there may be an instance where a consumer instead of getting his/her grievance resolved with the vendor / service provider approaches the consumer forum i.e. third party for resolution of grievance. An important question that arises in such scenario is that whether such aggrieved persons are satisfied with the offering of the forum or not. Moreover, in today's dynamic and digital world, third party complaints are on continuous rise. The present study focuses on identifying various factors which influence the satisfaction level of consumer complainants. Through well designed questionnaire, involving likert scale statements related to distributive, procedural and interactional justice, responses have been collected from 300 respondents from the district of Ludhiana from the State of Punjab. Analysis of responses, using factor analysis technique, has enabled the identification of factors such as convenience and cost, behavioural aspect and credentials of the personnel working with consumer dispute redressal forums, established under Consumer Protection Act 1986.
\end{abstract}

Index Terms: customer, customer satisfaction, consumer complainant, Complainant satisfaction, consumer dispute redressal forum.

\section{INTRODUCTION}

Transition from product and sales philosophy to holistic marketing philosophy, has given the business an opportunity to outperform competition through building strong marketer - customer relationship. Creating and retaining the customers is the thrust area of today's business. For customer retention, customer satisfaction is the area on which business needs to work upon. Recognizing the significance of customer retention and creation, customer centric firms are continuously and systematically measuring customer satisfaction in terms of how well their customers are being treated and what are the factors influencing customer satisfaction level. Based on the feedback / responses, business firms do incorporate suggestions made by customer and amend their operational and marketing policies.

Revised Manuscript Received on July 5, 2019.

Marinal Gupta, Assistant Professor in Commerce, Sri Aurobindo College of Commerce and Management, Ludhiana, India,

Sarang Narula, Assistant Professor, University School of Applied Management, Punjabi University, Patiala, India
Measurement of customer satisfaction has assumed an important role because business firms know that it's only a satisfied customer who will stay loyal for a longer period of time, by buying the products offered by business more frequently, having positive confirmation about the product, paying less attention to competing brands and be insensitive to price changes. Over a period of a time, customer satisfaction has become both a goal and a marketing tool for business firms as digital world is a promised platform for a customer to inform the rest of world about the positive as well negative disconfirmation.

Customer satisfaction, basically, is a post consumption evaluative judgement, where comparison of pre-purchase perceived hopefulness and actual performance of product or service (Gundersen, Heide and Olsson 1996). In other words, satisfaction is mental state of pleasure or discontentment resulting from deviation between perceived and actual performance. Positive disconfirmation (satisfaction) occur when product performance is better than expected / perceived and vice-versa. Customer centric firms aims at maximisation of customer satisfaction either by lowering the price of product or by improving after sale services or by going for non price competition or by having a well designed mechanism for getting feedback from customers (through customer-care department) where in their grievances are resolved as quickly as possible. As it's always not possible that a consumer has positive disconfirmation, business firms ensure the presence of grievance redressal department, whom customers can approach easily for getting their grievances addressed.

Inspite of conscious effort of business to resolve the issue, consumers may not be satisfied with the solution provided. In such a situation, the consumer is left with no other option, than approaching the consumer dispute redressal forums (CDRFs), established under Consumer Protection Act 1986 for getting his / her grievance resolved.

Here an important question arises, that is whether the CDRF's established under the Act are quite efficient to address the issues of customer complainants, whether consumer complainants are satisfied with the performance of CDRF's? and If Yes, what are the factors influencing the satisfaction level of consumer complainants. 
Though several studies have been conducted across the globe on customer satisfaction with regard to consumer protection agencies, yet there is no such study which examines the customer satisfaction level attained by consumer complainants in India. Understanding the need of the hour to check this wide gap in literature, the present study has been made with an objective -

A. To identify factors influencing the satisfaction level of consumer complainants with regard to working factors of CDRF's

B. To suggest measures to make consumer protection machinery more effective.

C. Dimensions considered for consumer complainant's satisfaction include:

1) Outcome associated with complaint that whether judgement delivered matches with application of consumer complainant.

2) Procedural aspects i.e. process of lodging the complaint

3) Interactional aspects i.e. behaviour and credentials of CDRF personnel

\section{REVIEW OF LITERATURE}

Zussman (1983) examined effectiveness of one form of government intervention with regard to consumer satisfaction in his study titled "Consumer Complaint Behavior and Third Party Meditation". He segregated individual complaint process in four stages namely recognition, registration, resolution and satisfaction stage. To measure the extent and nature of consumer complaints in 1979, selection of 1064 respondents was made with the help of stratified random sampling technique from the population residing within province of British Columbia. It was reported that $40 \%$ of sample respondents had at least one complaint out of which one third did not choose to take an action because they felt that registration of complaint will not do any good to them. $10 \%$ of those respondents who had a complaint did not go further for redressal of their complaint due to lack of knowledge about possible avenues of action. of the respondents who chose to register their complaint, $86.8 \%$ approached marketer/ service provider for resolution (out of which $67 \%$ complaints were resolved and $50 \%$ of such respondents expressed satisfaction with the outcome) whereas $13.2 \%$ sought help of a mediator. Due to accumulation of cases lying undecided with mediators, only $70 \%$ complaints could be resolved and less than one third of complainants expressed satisfaction with judgement delivered by mediator. Low expectation of complainant and non-resolution of complaint resulted into lower level of satisfaction.

Blodgett, Granbois and Walters (1993) in their paper titled "The effects of perceived justice on complainants' negative word-of-mouth behavior and repatronage intentions" tried to develop a model for consumer complaining behavior stating that consumers' adverse word of mouth along with repatronage intentions depend on complainant's own understanding of justice. As hypothesized, perceived justice was found to be the most influencing determinant of consumers' response post-delivery of justice. $49.1 \%$ of the variance for negative word-of-mouth and $68.5 \%$ of the variance for repatronage intentions has been reported by statistical analysis. It clearly reveals that customer satisfaction is of immense relevance as the cost of retaining an existing customer is much less than the cost of identifying a new customer.

To probe into the impact made by resolutionary business practices such as offering an apology, act of indemnification, facilitation, explanation and quick response to complainants' grievance on complainant satisfaction and to establish relationship between the variables namely complainant satisfaction, loyalty, trust and positive word of mouth, Warsame in the year 2008 conducted a study for which responses from 198 respondents, being users of telephone service providers in Mogadishu, Somalia, were gathered using a well structured questionnaire. Thereafter, analysis of the responses gathered was made using SPSS, where offering an apology, act of indemnification and facilitation emerged as major responses to complaints, having direct impact on complainant satisfaction. Of the mentioned responses, act of indemnification came up as the most effective response to complaints. Another inference that can be drawn from the analysis is that litigant's satisfaction exerts significant direct impact on litigant's loyalty, trust and positive word of mouth Orsingher, Valentini \& Deangelis (2009) in their paper titled "A meta-analysis of satisfaction with complaint handling in services" made an attempt to test how satisfaction with complaint handling is controlled by distributive, interactional, and / or procedural justice. For this purpose, meta-analysis of 60 studies of the antecedents indicated that it is the distributive justice which influences SATCOM the most. Whereas, procedural justice weakly impacts SATCOM.

Diane, Jones \& April (2013) conducted an exploratory research on disadvantaged consumer to develop constructs of understanding their satisfaction phenomenon. The purpose of exploratory research was to compare the existing satisfaction paradigm with the actual experiences of disadvantaged consumers to highlight limitations and deficiencies with the current theory. Satisfaction process of disadvantaged consumers was investigated through a series of five focus groups and nine in-depth interviews with disadvantaged consumers. Results indicated that disadvantaged consumers do not seem to form or articulate pre-purchase expectations, while performance, equity and affect appear to play strong roles in their satisfaction judgments. Equity in terms of interactional fairness was dominant for services. It was also found that disadvantaged consumers tend to be more passive when dissatisfied, accepting lesser service quality or poor product performance without complain. Thus need arises for extraordinary efforts to satisfy disadvantaged consumers and turn them into loyal customers. 


\section{Date Collection AND SAMPle Size}

A structured questionnaire is being prepared, where 38 likert scale statements related to above mentioned dimensions have been included and responses from 300 consumer complainants are gathered. After tabulation of responses collected, use of factor analysis technique helped in identifying factors influencing consumer complainants' satisfaction level with regard to working process of CDRF's established under the Act. The State of Punjab constitutes the population of study, which has 20 districts as per 2011 census. For this specific study, the district of Ludhiana is selected and respondents are selected using random sampling technique.

\section{Table 1: Measuring Sample Adequacy - KMO} and Barlett's Test

\begin{tabular}{|l|c|c|}
\hline \multicolumn{2}{|l|}{$\begin{array}{l}\text { Kaiser-Meyer-Olkin Measure of Sampling } \\
\text { Adequacy. }\end{array}$} & 0.927 \\
\hline Bartlett's Test of & Chi-Square & 11645.721 \\
\cline { 2 - 3 } Sphericity & $\mathrm{df}$ & 231 \\
\cline { 2 - 3 } & p-value & 0.000 \\
\hline
\end{tabular}

Interpretation: For KMO measure of sampling adequacy, a statistic indicating proportion of variance in variables caused by underlying factors, higher values lying between 0.5 and 1 indicate appropriateness of factor analysis. Highly significant results of KMO and Barlett's test of sphericity indicate appropriateness of the use of factor analysis.

Table 2: Communalities

\begin{tabular}{|l|c|c|}
\hline \multicolumn{1}{|c|}{ Statement } & Initial & Extraction \\
\hline $\begin{array}{l}\text { Availability of trained } \\
\text { personnel at the Forum }\end{array}$ & 1.000 & .976 \\
\hline Reliability of personnel & 1.000 & .955 \\
\hline $\begin{array}{l}\text { Adequacy of information } \\
\text { provided by the personnel }\end{array}$ & 1.000 & .951 \\
\hline $\begin{array}{l}\text { Accessibility of the } \\
\text { personnel }\end{array}$ & 1.000 & .980 \\
\hline $\begin{array}{l}\text { Knowledge of personnel at } \\
\text { the Forum }\end{array}$ & 1.000 & .927 \\
\hline $\begin{array}{l}\text { Patient listening to the } \\
\text { problem by the personnel }\end{array}$ & 1.000 & .810 \\
\hline $\begin{array}{l}\text { Professional skills of the } \\
\text { personnel, meant for } \\
\text { handling complaint. }\end{array}$ & 1.000 & .762 \\
\hline $\begin{array}{l}\text { Willingness of the personnel } \\
\text { to entertain the complaint }\end{array}$ & 1.000 & .935 \\
\hline $\begin{array}{l}\text { Timeliness of information } \\
\text { provided by the personnel }\end{array}$ & 1.000 & .870 \\
\hline Quick response to queries & 1.000 & .874 \\
\hline $\begin{array}{l}\text { Personalized attention by the } \\
\text { personnel }\end{array}$ & 1.000 & .840 \\
\hline $\begin{array}{l}\text { Transparent and fair dealing } \\
\text { by the personnel }\end{array}$ & 1.000 & .815 \\
\hline $\begin{array}{l}\text { Support extended by social } \\
\text { groups or NGOs }\end{array}$ & 1.000 & .891 \\
\hline Support extended & 1.000 & \\
\hline
\end{tabular}

\begin{tabular}{|l|l|l|}
\hline $\begin{array}{l}\text { broadcasting and print } \\
\text { media }\end{array}$ & \\
\hline $\begin{array}{l}\text { Support extended by } \\
\text { voluntary consumer } \\
\text { organizations }\end{array}$ & 1.000 & .828 \\
\hline Ease of lodging complaint & 1.000 & .873 \\
\hline $\begin{array}{l}\text { Amount of money required } \\
\text { to lodge a complaint }\end{array}$ & 1.000 & .917 \\
\hline Litigation cost & 1.000 & .918 \\
\hline Computerization of the work & 1.000 & .803 \\
\hline $\begin{array}{l}\text { Convenient location } \\
\text { Convenient working hours } \\
\text { of the Forum }\end{array}$ & 1.000 & .917 \\
\hline $\begin{array}{l}\text { Waiting time in queues for } \\
\text { various queries / deposit of } \\
\text { complaint form and } \\
\text { prescribed fees / submission } \\
\text { of information etc }\end{array}$ & 1.000 & .537 \\
\hline
\end{tabular}

Interpretation: Communalities are sum of squared factor loadings. In PCA, the initial value of the communality is always 1. Variable with high extraction value is well represented in the common factor space while variables with low extraction value isn't well suited for factor analysis. Table 2, which shows the communalities for the selected variables, has been found with high extraction values thus data is reliable for conducting factor analysis. Small values $(<0.5)$ indicating variables, that do not fit well with the factor solution, have been dropped from the analysis.

Table 3: Total Variance Explained

\begin{tabular}{|c|c|c|c|c|c|c|c|c|c|}
\hline \multirow[b]{2}{*}{ Component } & \multicolumn{3}{|c|}{ Initial Eigen values } & \multicolumn{3}{|c|}{$\begin{array}{c}\text { Extraction Sums of Squared } \\
\text { Loadings }\end{array}$} & \multicolumn{3}{|c|}{$\begin{array}{l}\text { Rotation Sums of Squared } \\
\text { Loadings }\end{array}$} \\
\hline & Total & \begin{tabular}{|c|}
$\%$ of \\
Variance \\
\end{tabular} & $\begin{array}{c}\text { Cumulative } \\
\% \\
\end{array}$ & Total & \begin{tabular}{|c|}
$\%$ of \\
Variance \\
\end{tabular} & \begin{tabular}{|c|}
$\begin{array}{c}\text { Cumulative } \\
\%\end{array}$ \\
\end{tabular} & Total & \begin{tabular}{|c|}
$\%$ of \\
Variance \\
\end{tabular} & $\begin{array}{c}\text { Cumulative } \\
\%\end{array}$ \\
\hline 1 & 13.897 & 63.169 & 63.169 & 13.897 & 63.169 & 63.169 & 5.553 & 25.241 & 25.241 \\
\hline 2 & 2.617 & 11.896 & 75.065 & 2.617 & 11.896 & 75.065 & 5.409 & 24.588 & 49.829 \\
\hline 3 & 1.405 & 6.386 & 81.451 & 1.405 & 6.386 & 81.451 & 4.854 & 22.063 & 71.892 \\
\hline 4 & 1.245 & 5.657 & 87.108 & 1.245 & 5.657 & 87.108 & 3.348 & 15.216 & 87.108 \\
\hline 5 & .556 & 2.527 & 89.635 & & & & & & \\
\hline 6 & 375 & 1.702 & 91.337 & & & & & & \\
\hline 7 & .323 & 1.468 & 92.804 & & & & & & \\
\hline 8 & .297 & 1.350 & 94.155 & & & & & & \\
\hline 9 & .239 & 1.086 & 95.241 & & & & & & \\
\hline 10 & .217 & .985 & 96.226 & & & & & & \\
\hline 11 & .176 & .802 & 97.028 & & & & & & \\
\hline 12 & .131 & .595 & 97.623 & & & & & & \\
\hline 13 & .110 & .499 & 98.122 & & & & & & \\
\hline 14 & .100 & .454 & 98.576 & & & & & & \\
\hline 15 & .083 & 377 & 98.953 & & & & & & \\
\hline 16 & .071 & .321 & 99.274 & & & & & & \\
\hline 17 & .060 & .273 & 99.547 & & & & & & \\
\hline 18 & .039 & .177 & 99.725 & & & & & & \\
\hline 19 & .030 & .138 & 99.863 & & & & & & \\
\hline 20 & .018 & .081 & 99.944 & & & & & & \\
\hline 21 & .009 & .039 & 99.983 & & & & & & \\
\hline 22 & .004 & .017 & 100.000 & & & & & & \\
\hline
\end{tabular}


Interpretation: Table reveals that how many variables can be clubbed together to make a single factor. A factor with lower eigen value has been ignored as it's contributing little to the explanation of variances. Therefore, only factors with Eigen value more than one are retained. Four factors have been derived from twenty-two variables which show $87.108 \%$ variance. It is important to be noted that the first factor reports $63.169 \%$ of the variance whereas the second, third and fourth factor accounts for $11.896 \%, 6.386 \%$ and $5.657 \%$ variance respectively.



Figure 1: Scree Plot

Interpretation: Figure 1 shows the scree plot of the Eigen values for all identified factors for determining number of factors to be retained. Graph exposits that the curve begins to flatter after fourth variable, therefore only four factors have been retained.

Table 4: Rotated Component Matrix

\begin{tabular}{|l|c|c|c|c|}
\hline \multicolumn{4}{|c|}{ Statement (s) } & \multicolumn{3}{|c|}{ Component } \\
\cline { 2 - 5 } & 1 & 2 & 3 & 4 \\
\hline $\begin{array}{l}\text { Amount of money required to lodge a } \\
\text { complaint }\end{array}$ & .897 & & & \\
\hline Litigation cost & .893 & & & \\
\hline $\begin{array}{l}\text { Convenient working hours of the } \\
\text { Forum }\end{array}$ & .882 & & & \\
\hline Convenient location & -882 & & & \\
\hline Ease of lodging complaint & .844 & & & \\
\hline Computerization of the work & .731 & & & \\
\hline $\begin{array}{l}\text { Willingness of the personnel to } \\
\text { entertain the complaint }\end{array}$ & & .898 & & \\
\hline $\begin{array}{l}\text { Timeliness of information provided } \\
\text { by the personnel }\end{array}$ & & .859 & & \\
\hline Quick response to queries & & .834 & & \\
\hline $\begin{array}{l}\text { Personalized attention by the } \\
\text { personnel }\end{array}$ & & .810 & & \\
\hline $\begin{array}{l}\text { Trangparent and fair dealing by the } \\
\text { personnel }\end{array}$ & & .806 & & \\
\hline $\begin{array}{l}\text { Patient ligtening to the problem by the } \\
\text { personnel }\end{array}$ & & .774 & & \\
\hline Knowledge of personnel at the Forum & & & .818 & \\
\hline Accessibility of the personnel & & & .814 & \\
\hline Reliability of personnel & & & .806 & \\
\hline $\begin{array}{l}\text { Availability of trained personnel at } \\
\text { the Forum }\end{array}$ & & & .805 & \\
\hline $\begin{array}{l}\text { Adequacy of information provided by } \\
\text { the personnel }\end{array}$ & & & .787 & \\
\hline $\begin{array}{l}\text { Professional skills of the personnel, } \\
\text { meant for handling complaint. }\end{array}$ & & & .669 & \\
\hline $\begin{array}{l}\text { Support extended by social groups or } \\
\text { NGOs }\end{array}$ & & & & .826 \\
\hline $\begin{array}{l}\text { Support extended by voluntary } \\
\text { consumer organizations }\end{array}$ & & & & .823 \\
\hline $\begin{array}{l}\text { Support extended by broadcasting } \\
\text { and print media }\end{array}$ & & & & .767 \\
\hline $\begin{array}{l}\text { Waiting time in queues for various } \\
\text { queries / depogit of complaint form } \\
\text { and prescribed fees / submission of } \\
\text { information etc }\end{array}$ & & & & \\
\hline
\end{tabular}

Interpretation: To improvise study and it's interpretability, the variables are rotated by using varimax rotation to find the underlying constructs and their relationship. The variables are chosen to represent the various components enhancing satisfaction with regard to working process of consumer dispute redressal forums established under Consumer Protection Act 1986. The result of rotated component from table 4 identifies four important underlying components which are most correlated. Six statements titled as amount of money required to lodge a complaint, litigation cost, convenient working hours of the Forum, convenient location, ease of lodging complaint and computerization of the work load on first factor namely Cost and Convenience factor. The loading of the variables first, second, third, fourth, fifth and sixth on the first factor are $.897, .893, .882,882, .844$ and .731 respectively. Communality of the factors is 25.241 percent, which means approximately $25.241 \%$ variance is being captured by the extracted factors.

Again six statements namely willingness of the personnel to entertain the complaint, timeliness of information provided by the personnel, quick response to queries, personalized attention by the personnel, transparent and fair dealing by the personnel and Patient listening to the problem by the personnel constitute second factor namely behavioural aspect of personnel. The loading of the first, second, third, fourth, fifth and sixth variables on the second factor are $.898, .859$, $.834,810, .806$ and .774 . The communality of the factors is 24.588 percent, which means approximately $24.588 \%$ variance is being captured by the extracted factors.

Third factor namely credentials of the personnel loaded on the statements such asknowledge of personnel at the Forum, accessibility and reliability of the personnel, availability of trained personnel at the Forum, adequacy of information provided by the personnel and professional skills of the personnel, meant for handling complaint. The loading of the first, second, third, fourth, fifth and sixth variables on the third factor are $.818, .814, .806, .805, .787$ and .669 . The communality of the factors is $22.063 \%$, which means approximately $22.063 \%$ variance is being captured by the extracted factors.

Four statements which loaded on fourth factor namely support extended by outside sources are support extended by social groups or NGOs, voluntary consumer organizations (VCOs) and broadcasting and print media and waiting time in queues for various queries / deposit of complaint form and prescribed fees / submission of information etc. The loading of the first, second, third and fourth variables on the fourth factor are $.826, .823, .767$ and .574 . The communality of the factors is 15.216 percent, which means approximately $15.216 \%$ variance is being captured by extracted factors. 
Table 5: Reliability Statistics

\begin{tabular}{|c|c|}
\hline Cronbach's Alpha & N of Items \\
\hline .967 & 8 \\
\hline
\end{tabular}

Interpretation: Results of reliability statistics, determined by computing Cronbach's alpha, have been presented in table 5. Cronbach's coefficient alpha of 0.967 is considered as excellent for confirmatory purposes.

Table 6: Magnitude and direction of the relationship between different explanatory variables

\begin{tabular}{|c|c|c|c|c|c|}
\hline \multicolumn{6}{|c|}{ Correlations } \\
\hline & & Factor-A & Factor-B & Factor-C & Factor-D \\
\hline \multirow[t]{3}{*}{ Factor-A } & Pearson Correlation & 1 & $.507^{* *}$ & $.686^{* *}$ & $.575^{* *}$ \\
\hline & p-value & & .000 & .000 & .000 \\
\hline & $\mathrm{N}$ & & 300 & 300 & 300 \\
\hline \multirow[t]{3}{*}{ Factor-B } & Pearson Correlation & & 1 & $.698^{* *}$ & $.643^{* *}$ \\
\hline & p-value & & & .000 & .000 \\
\hline & $\mathbf{N}$ & & & 300 & 300 \\
\hline \multirow[t]{3}{*}{ Factor-C } & Pearson Correlation & & & 1 & $.692^{* *}$ \\
\hline & p-value & & & & .000 \\
\hline & $\mathrm{N}$ & & & & 300 \\
\hline
\end{tabular}

Interpretation: To measure the magnitude and direction of the relationship between different explanatory variables Pearson Correlation analysis is made. The interdependence among variables is a common characteristic of most multivariate techniques and the correlation matrix is used to display correlation coefficient between these variables. The matrices form the basis for the computation and understanding of the nature of relationships, purpose for conducting correlation analysis is to spot the presence of multicollinerarity between different explanatory variables. Analysis reveals a positive and significant correlation between factor $\mathrm{A}$ and the remaining variables i.e., factor $\mathrm{B}$, factor $C$ and factor D. Similar results are seen in case of factor $\mathrm{B}$, factor $\mathrm{C}$ and factor $\mathrm{D}$. It is evident from the table 6 that all the correlations are positive and significant.

\section{CONCluSion}

It can be inferred from the analysis that a consumer, who approached the consumer dispute redressal forum after having negative disconfirmation with a business, was satisfied with the way his complaint was taken up by the concerned personnel, the cost involved in lodging the complaint, and ease in the dispute redressal mechanism. Factors analysis revealed that because of convenience and cost involved, behaviour and credentials of CDRF personnel, and support extended by outside sources which are involved in creating awareness among consumers regarding various consumer protection legislations, complainants felt satisfied. Therefore, it can be concluded that the complainants are generally satisfied with the consumer grievances mechanism in Consumer Dispute Redressal Forum but disappointed with the behaviour of the marketers.

\section{REFERENCES}

1. Halstead Diane, Jones Michael A and Cox April N, 'Satisfaction and the disadvantaged consumer, 'Journal of consumer satisfaction, dissatisfaction and complaining behaviour', Vol. 20, 2013, p.p. 15-35.

2. Jeffrey G. Blodgett, Donald H. Granbois, Rockney G. Walters, The effects of perceived justice on complainants' negative word-of-mouth behavior and repatronage intentions, Journal of Retailing, Volume 69, Issue 4, Winter 1993, Page 399-428.

3. Orsingher, Chiara \& Valentini, Sara \& Deangelis, Matteo. (2009). A meta-analysis of satisfaction with complaint handling in services. Journal of the Academy of Marketing Science. 38. 2009, 169-186.

4. Shannon Andetson, Lisa Klein Pearo and Sally K. Widener, 'Drivers of service satisfaction: linking customer satisfaction to the service concept and customer characteristics, 'Journal of service research', Vol. 10, no.4, may 2014, pp.365-381.

5. Warsame Bashir A., "The impact of consumer complaints handling on complainant satisfaction and behavioral outcomes: A study among the telephone service providers in mogadishu, Somalia", Research report, 2008.

6. Zussman D. (1983) "Consumer Complaint Behavior and Third Party Meditation” Canadian Public Policy, Vol. 9, No.2 (Jun 1983), pp.223-235.

\section{AUTHORS PROFILE}

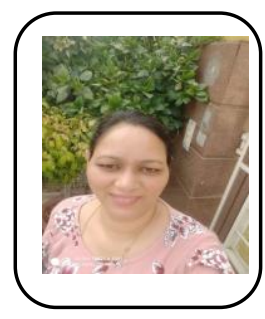

Marinal Gupta presently working as an Assistant Professor in Commerce, Sri Aurobindo College of Commerce and Management, Ludhiana. Her research areas are Consumer behavior and Research performance.

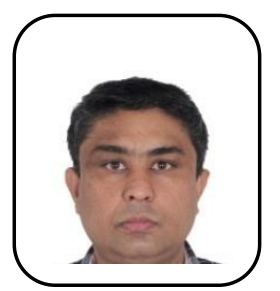

Dr.Sarang Narula is presently working as Assistant Professor in the University School of Applied Management. He has done his bachelor's in Commerce from Punjabi University and Masters in Management from University of Pune. He has nearly fourteen years of experience which includes both of Industry and Teaching. He has worked for around six years in corporate sector which includes best of Telecom \& Insurance sector. After having a stint in industry, he has joined Punjabi University as Assistant Professor in Management and has been teaching both post graduate and under graduate classes since past ten years. He has attended as well as presented research papers at various National and International conferences. Eight research scholars are presently pursuing $\mathrm{PhD}$ under his guidance and two international students have already been awarded the $\mathrm{PhD}$ degrees. 